Check for updates

Cite this: RSC Adv., 2017, 7, 31899

Received 29th November 2016

Accepted 12th June 2017

DOI: 10.1039/c6ra27478a

rsc.li/rsc-advances

\section{Design, synthesis and biological evaluation of valepotriate derivatives as novel antitumor agents $\uparrow$}

\author{
Bo Zhang, $t^{a b}$ Ruiying Guo, $t^{c}$ Yongzhou Hu, ${ }^{c}$ Xiaowu Dong, (D) Nengming Lin, ${ }^{\mathrm{b}}$ \\ Xiaoyang Dai, ${ }^{a}$ Honghai $\mathrm{Wu}^{,}{ }^{a}$ Shenglin $\mathrm{Ma}^{* \mathrm{~b}}$ and Bo Yang ${ }^{* a}$
}

Natural products remain the largest resources of lead compounds that can be used to develop novel anticancer drug candidates. Based on deacetylisovaltratum, a natural product with promising anticancer activity, herein we designed and synthesized of a series of valepotriate derivatives with a novel skeleton from commercially available genipin. In addition, a structure-activity relationship study demonstrated the importance of an epoxy group on the C1-position and the preferable size of the sidechain ((5methylhexanoyl)oxy) on the C-7 position of valepotriates for their cytotoxic activities. The most potent compound $1 \mathrm{e}$ showed moderate to good $I_{50}$ values against various cancer cells, ranging from 10.7 to $50.2 \mu \mathrm{M}$, which are comparable to that of deacetylisovaltratum. Additionally, we demonstrate that mitochondrion-mediated apoptosis would be its mechanism of action, thus enlightening the further development of novel valepotriate derivatives.

\section{Introduction}

Natural product research continues to explore a variety of lead compounds, which are potential templates for the development of new anticancer drug candidates. ${ }^{1-3}$ However, challenges remain unsolved in either the isolation or purification of bioactive natural products; thus semisynthesis becomes a preferable method to obtain bioactive compounds. ${ }^{4}$ The semisynthetic strategy is widely used when the precursor molecules are structurally complex, or difficult produce by total synthesis, such as anticancer drugs (i.e. paclitaxel, etoposide, and irinotecan), antimalarial drugs (i.e. roxithromycin) and antibiotics (i.e. cefixime) (Fig. 1).

Valerian is a very important genus of plants used as a medicinal herb in many areas of the world, the roots and rhizomes of which have been used for the treatment of epilepsy, hysteria, nervous disorders, neurasthenia and emotional stress. ${ }^{5-9}$ In particular, Patrinia heterophylla Bunge, belonging to the genus Valerian, showed anticancer activity against

\footnotetext{
${ }^{a}$ Zhejiang Province Key Laboratory of Anti-Cancer Drug Research, Institute of Pharmacology and Toxicology, School of Pharmaceutical Sciences, Zhejiang University, Hangzhou, Zhejiang 310058, P. R. China. E-mail: yang924@zju.edu.cn; Tel: $+86-57188208400$

${ }^{b}$ Translational Medicine Research Center, Nanjing Medical University, Affiliated Hangzhou Hospital, Hangzhou First People's Hospital, Hangzhou, Zhejiang 310006, P. R. China. E-mail: mashenglin@medmail.com.cn; Tel: +86-57156007908

${ }^{c}$ ZJU-ENS Joint Laboratory of Medicinal Chemistry, Zhejiang Province Key Laboratory of Anti-Cancer Drug Research, College of Pharmaceutical Sciences, Zhejiang University, Hangzhou, 310058, P. R. China

$\dagger$ Electronic supplementary information (ESI) available: NMR spectra of the synthesized compounds. See DOI: 10.1039/c6ra27478a

\$ These authors contributed equally to this work.
}

metrocarcinoma and cervical cancer in ancient China, whereas the biological components responsible for its anticancer activity are not fully recognized. ${ }^{\mathbf{1 0 , 1 1}}$ Indeed, a variety of pharmacologically active components (e.g. monoterpenes, valepotriates, and sesquiterpenes) have been isolated and characterized. ${ }^{\mathbf{1 2 , 1 3}}$ Among them, valepotriates, belonging to the family of iridoids with a 10-carbon basic skeleton, showed their significant activity against cancer cells. ${ }^{\mathbf{1 - 3 , 1 4}}$ Recently, we found that deacetylisovaltratum, a compound belonging to the class of valepotriates, could effectively cause G2/M-phase arrest in gastric cancer cells by disrupting tubulin polymerization, and inducing mitochondrion-dependent apoptosis..$^{15,16}$ Considering the unique structure of epoxy group in deacetylisovaltratum, the alkylating properties could be responsible for its potent anti-
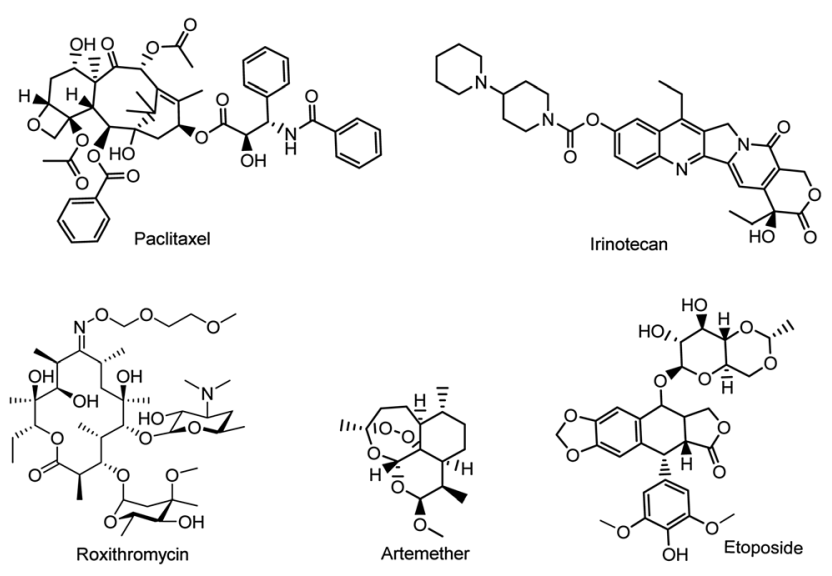

Fig. 1 Examples of semisynthetic drugs. 

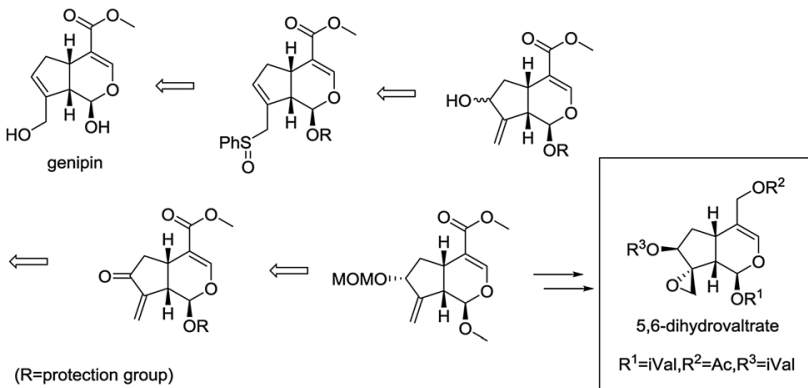

( $\mathrm{R}=$ protection group)

Fig. 2 Murakami's synthetic strategy

cancer activity. Moreover, the structural diversity might change its physicochemical properties and also its intracellular activities. However, due to the lack of structural diversity in natural valepotriates, as well as the difficulty in synthetic procedures, the structural-activity relationship (SAR) studies of valepotriate analogues is very rare, which hampers the development of valepotriate as novel anti-cancer agents. Therefore, the exploration of the crucial structural requirement of valepotriates for anticancer activities is particularly needed. In this study, we intend to acquire series of valepotriate derivatives via semisynthesis and to study the biological activity of these compounds.

Recently, Murakami et al. reported the concise synthesis of 5,6-dihydrovaltrate from commercially available iridoid genipin, providing a novel semisynthetic route in structurally optimization of valepotriates (Fig. 2). ${ }^{17,18}$ As part of our continued interest in the area of chemical modification of natural products, ${ }^{19,20}$ herein, we designed, synthesized a series of valepotriate derivatives with novel skeleton from genipin using slightly modified Murakami's method. Noteworthy, some crucial SAR clues were found after investigating the effect of epoxy and length of aliphatic side chain on cytotoxicity against a variety of cancer cells. More significantly, some compounds showed superior cytotoxic activities than that of deacetylisovaltratum. In addition, mitochondrion-mediated apoptosis was significantly observed, which would be the exact action mechanism of its cytotoxic activities, thus enlightening the further development of novel valepotriate derivatives.

\section{Results and discussion}

\subsection{The synthesis of valepotriate derivatives}

The synthesis of compounds $\mathbf{1 a - h}$ started with genipin is illustrated in Scheme 1. At first, genipin 2 was treated by Amberlyst-15 resins in methanol to afford methyl acetal 3, which was submitted to phenylsulfidation using diphenyldisulfide and tributylphosphane in toluene to give phenylsulfide 4. After acidic hydrolysis of the methyl acetal with $10 \% \mathrm{HCl}-$ THF, the resulting hemiacetal $\mathbf{5}$ was coupled with isovaleric acid in the presence of isovaleric acid, 1,1'-carbonyldiimidazole (CDI) and 1,8-diazabicyclo[5.4.0]undec-7-ene (DBU) to yield isovaleryl acetal 6. After oxidation of 6 with oxone in methanol, the resulting sulfoxide was subjected to Mislow-Evans rearrangement with trimethyl phosphite in $\mathrm{MeOH}$ to afford allyl alcohol 7. In this rearrangement procedure, the reaction time was quite crucial for the conversion, which should be carefully monitored by TLC analysis. Then, stereoselective epoxidation associated with the adjacent hydroxyl group using tert-butyl hydroperoxide (TBHP) and vanadium oxyacetylacetonate $\left[\mathrm{VO}(\mathrm{acac})_{2}\right]^{17,18,21,22}$ afforded epoxyalcohols 8. ${ }^{\mathbf{1 8 2 2}}$ Finally, desired compounds 1a-h was obtained by introduction of the appropriate aliphatic acid group to C-7 of compound 7 by Mitsunobu inversion using diethyl azodicarboxylate (DEAD) and triphenylphosphine (Fig. 3).
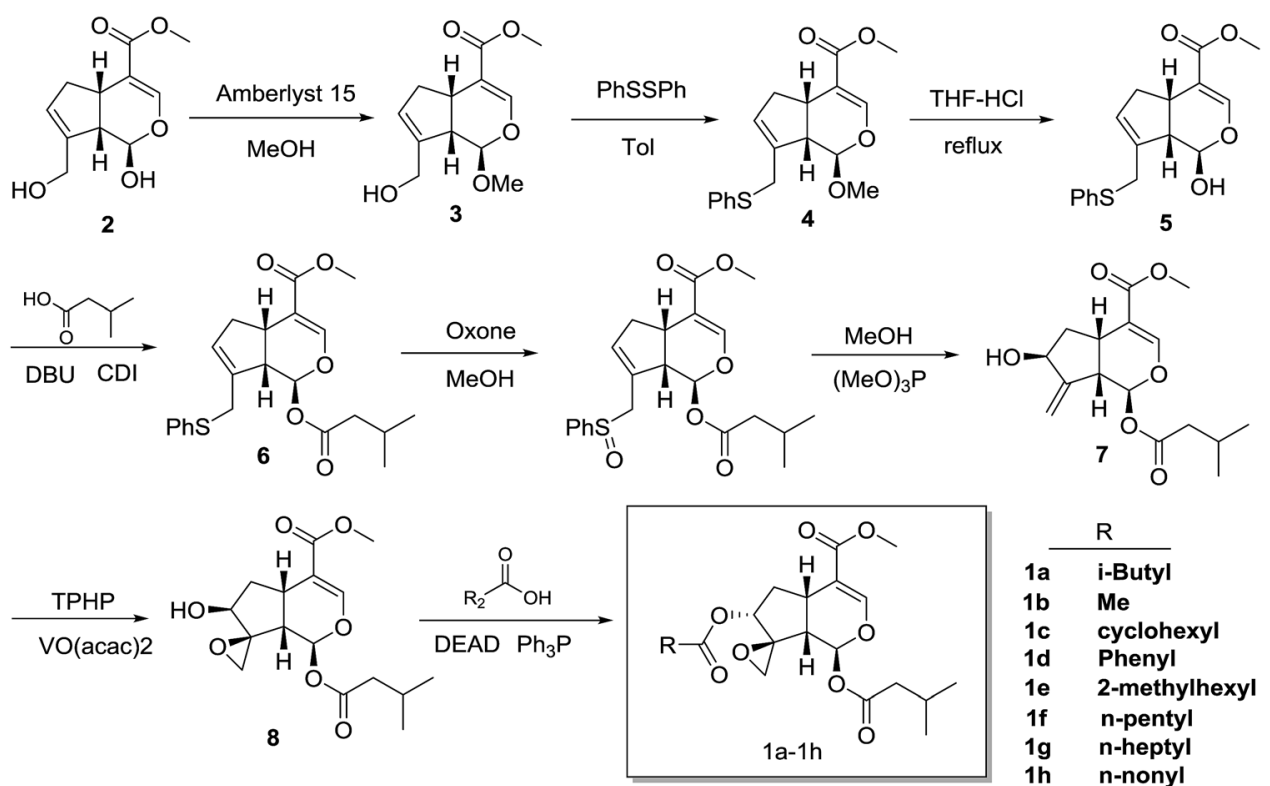

Scheme 1 Synthesis of valepotriate derivatives. Reagents and conditions: (a) Amberlyst-15, MeOH; (b) PhSSPh, Tol; (c) 10\%HCl, THF; (d) isovaleric acid, DBU, CDI; (e) oxone, $\mathrm{MeOH}$; (f) (MeO) ${ }_{3} \mathrm{P}, \mathrm{MeOH}$; (g) TPHP, VO(acac) 2 , Tol; (h) appropriate acid, DEAD, Ph $\mathrm{P}, \mathrm{Tol}$. 


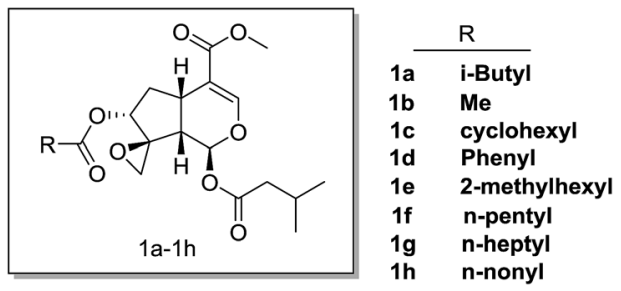

Fig. 3 The structures of valepotriate derivatives $1 \mathrm{a}-1 \mathrm{~h}$ in this study.

\subsection{Cytotoxicity of compounds $1 \mathrm{a}-\mathrm{h}$ against various cancer cells}

To investigate whether these compounds could suppress the growth of cancer cells, anti-proliferative effect was tested against various cancer cell lines, including pancreatic cancer cells (SW1990, BXPC3, CAPAN2, CFPAC, PANC1), breast cancer cells (BT474, MCF7, MDA-MB-231), gastric cancer cells (AGC, HGC-27, KATOIII) and lung cancer cells (H1795) (Table 1). As expected, some of these compounds (i.e. 1c, 1d, 1e) showed comparable cytotoxic activities as the parental compound deacetylisovaltratum, suggesting that the novel skeleton with methoxycarbonyl on C4-position of valepotriate remained the anticancer activities. Moreover, we found epoxy group on C1position of valepotriate was very crucial by comparing with the anticancer activities of $7 \mathbf{a}$ and deacetylisovaltratum, which was in consistent with the work of Murakami et al. ${ }^{22}$ In another study, R. Bos et al. reported the cytotoxicity of valepotriates analogues against GL4 and COLO 320 cells with $\mathrm{IC}_{50}$ values ranging from 1 to $6 \mu \mathrm{M}^{12}$ Additionally, three valepotriate isomers isolated by S. Lin et al. displayed moderate cytotoxicity against various cancer cell lines with $\mathrm{IC}_{50}$ values varied from 2.8 to $8.3 \mu \mathrm{M}^{23}$ In this study, 1e showed comparable cytotoxic activity as previously reported valepotriate analogues. In further SAR analysis, either shortening or prolonging the sidechain (i.e. 1a, 1b, 1f, 1g, 1h) undermined its biological activities, revealing that (5-methylhexanoyl)oxy group on C-7 position would be preferable lipophilicity towards cancer cells. Meanwhile, the replacement of (5-methylhexanoyl)oxy group with aromatic (1d) and cyclohexyl (1c) substituents reduced its cytotoxic activity. Based on our efforts in structural optimization of valepotriate analogues, we successfully discovered a potent semisynthetic compound 1e bearing unique skeleton distinguished from deacetylisovaltratum which was previously identified as potent natural anti-cancer agent.

\subsection{Cytotoxicity of 1e in human lung cancer H1975 cells}

Human lung cancer H1975 cell harbours both L858R and T790M mutation in epidermal growth factor receptor (EGFR), thus it is resistant to first-generation EGFR tyrosine inhibitor such as gefitinib or erlotinib. As recently reported, several plants-derived compounds possessed anti-proliferation activity against $\mathrm{H} 1975$, and the $\mathrm{IC}_{50}$ value varied from 3 to $15 \mu \mathrm{M} .{ }^{24-26}$ In our study, the cytotoxicity of $1 \mathrm{e}$ was determined by CCK-8 assay in human lung cancer H1975 cells (Fig. 4). 1e exhibited both time- and concentration-dependent cytotoxicity against $\mathrm{H} 1975$ cells. The $\mathrm{IC}_{50}$ values of 48 and $72 \mathrm{~h}$ treatment with 1e were 27.4 and $13.1 \mu \mathrm{M}$ respectively.

\subsection{Compound 1e triggered apoptosis in H1975 cells}

Apoptosis was usually involved in the proliferation inhibitory effect caused by natural compound. ${ }^{27}$ Annexin V/PI staining was used to characterize the early and late apoptotic cells after cells were treated with indicated concentrations of $1 \mathrm{e}$ for $48 \mathrm{~h} .{ }^{28} \mathrm{In}$ H1975 cells, treatment with $20 \mu \mathrm{M}$ of 1 e yielded a $35 \%$ apoptosis rate, which was in consistent with the $\mathrm{IC}_{50}$ value of $48 \mathrm{~h}$ treatment (Fig. 5A). By comparing the apoptosis induction activity of 1e with other natural derived agents in $\mathrm{H} 1975$ cells, 1e exhibited superior anti-cancer activity than cordycepin, but slightly less effective than shikonin..$^{24,25}$ Meanwhile, depolarized mitochondria membrane potential was detected after $24 \mathrm{~h}$ treatment with $20 \mu \mathrm{M}$ of $1 \mathrm{e}$ (Fig. 5B). In addition, DAPI stain was used to verify the occurrence of apoptosis. After $48 \mathrm{~h}$ treatment with $20 \mu \mathrm{M}$ of 1e, nucleus with shrunk size and intensified fluorescence were seen under fluorescence microscopy. Moreover, apoptotic

Table 1 Cytotoxic activities of valepotriate derivatives $1 \mathrm{a}-\mathrm{h}$ against various cancer cells ${ }^{a}$

Cytotoxic activities, $\mathrm{IC}_{50}(\mu \mathrm{M})$

\begin{tabular}{|c|c|c|c|c|c|c|c|c|c|c|c|}
\hline Cell lines & Cancer type & DI & $7 \mathbf{a}$ & 1a & $1 b$ & $1 \mathrm{c}$ & 1d & 1e & 1f & $1 \mathrm{~g}$ & $1 \mathrm{~h}$ \\
\hline SW1990 & Pancreatic cancer & 34.9 & 85.2 & 59.1 & $>100$ & 40.2 & 54.9 & 26.1 & N.T. & N.T. & N.T. \\
\hline BXPC3 & & 14.4 & 24.6 & 48.2 & $>100$ & 28.1 & 37.1 & 25.1 & N.T. & N.T. & N.T. \\
\hline CAPAN2 & & 17.5 & 63.7 & 37.4 & 53.8 & 33.9 & 68.0 & 31.6 & 40.7 & $>100$ & $>100$ \\
\hline CFPAC & & 13.0 & 87.7 & 47.4 & 52.0 & 29.5 & 60.9 & 27.9 & 54.3 & 32.0 & 53.9 \\
\hline PANC1 & & 14.8 & $>100$ & 86.9 & N.T. & 48.0 & 66.9 & 20.6 & N.T. & N.T. & N.T. \\
\hline BT474 & Breast cancer & 24.3 & N.T. & 97.8 & $>100$ & 21.4 & 54.0 & 50.2 & N.T. & N.T. & N.T. \\
\hline MCF7 & & 27.5 & 51.2 & 77.4 & $>100$ & 18.1 & 19.8 & 10.7 & N.T. & N.T. & N.T. \\
\hline MDA-MB-231 & & 23.1 & 51.0 & 42.8 & $>100$ & 12.7 & 27.3 & 13.2 & N.T. & N.T. & N.T. \\
\hline AGS & Gastric cancer & 7.7 & 53.2 & 26.3 & $>100$ & 28.9 & 36.9 & 22.9 & 55.7 & 59.5 & $>100$ \\
\hline HGC-27 & & 14.8 & 25.7 & 47.5 & $>100$ & 20.9 & 28.2 & 21.5 & $>100$ & 54.0 & 26.6 \\
\hline KATOIII & & 32.2 & N.T. & N.T. & N.T. & N.T. & N.T. & N.T. & 48.8 & 51.2 & 92.5 \\
\hline H1975 & Lung cancer & 14.3 & 21.0 & 25.8 & 93.0 & 28.2 & 15.9 & 11.3 & N.T. & N.T. & N.T. \\
\hline
\end{tabular}

${ }^{a}$ N.T. indicates not detectable. 


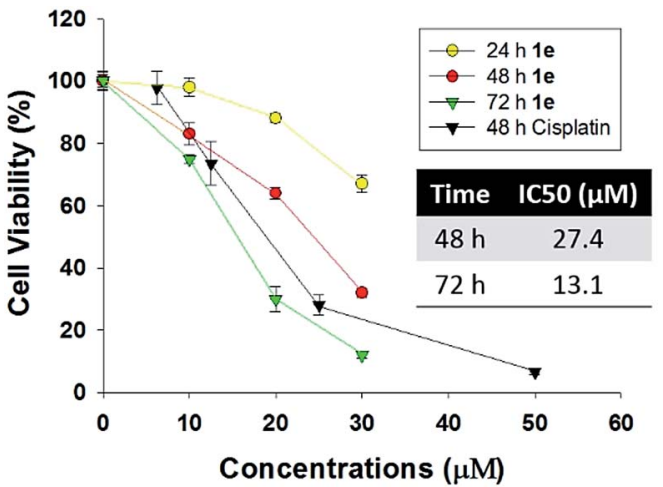

Fig. 4 The inhibitory effect of $1 \mathrm{e}$ on human lung cancer cell line H1975. H1975 cells were seeded in 96-well plates and then treated with 1e as indicated. Treatment was washed off after 24, 48, 72 or $96 \mathrm{~h}$ and cell viability was calculated using CCK- 8 assay.
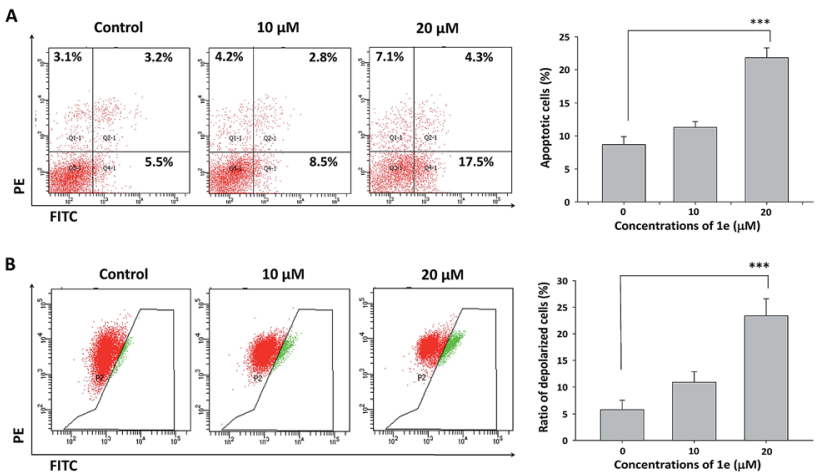

Fig. 5 1e triggered mitochondrion-dependent apoptosis in $\mathrm{H} 1975$ cells. (A) H1975 cells were seeded in 6-well plate and cultured for $24 \mathrm{~h}$. Cells were treated with $1 \mathrm{e}$ for $48 \mathrm{~h}$ before staining and followed by flow cytometric analysis. (B) $\mathrm{H} 1975$ cells were seeded in 6 -well plate and cultured for $24 \mathrm{~h}$. Cells were treated with $1 \mathrm{e}$ for $12 \mathrm{~h}$ before JC-1 stain and flow cytometric analysis. Three independent experiments were quantitatively analyzed. Each bar represented the mean $\pm S D$. $* * * P<0.001$

bodies could be observed at $20 \mu \mathrm{M}$ of 1e, suggesting that $\mathrm{H} 1975$ cells were undergoing apoptosis (Fig. 6).

\subsection{Compound 1e induced caspase-dependent apoptosis}

Mitochondrion plays a critical role in the apoptosis caused by natural compounds. In H1975 cells, reduced expression of Bcl-
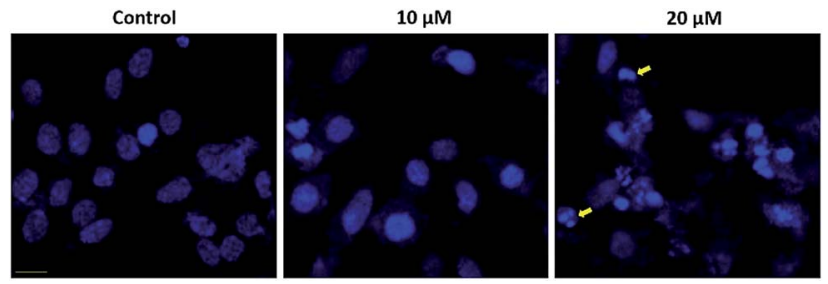

Fig. $6 \mathrm{H} 1975$ cells were seeded in 6-well plate and cultured for $24 \mathrm{~h}$. Cells were treated with $1 \mathrm{e}$ for $48 \mathrm{~h}$ before DAPI stain and observed under fluorescence microscopy. Yellow arrows indicates apoptotic bodies. Scale bar $=20 \mu \mathrm{m}$.
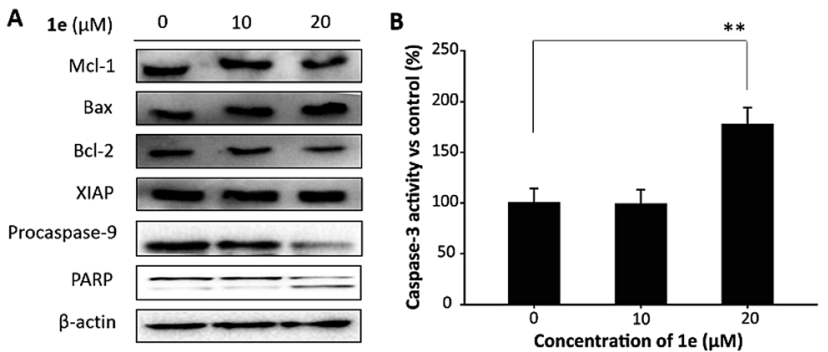

Fig. 7 1e triggered apoptosis in $\mathrm{H} 1975$ cells. (A) After treated with $1 \mathrm{e}$ for $48 \mathrm{~h}$, cells were lysed and proteins were analysed by western blot. (B) After treated with 1e for $48 \mathrm{~h}$, cells were lysed and caspase- 3 activity was analysed using Caspase-3 Colorimetric Assay Kit (Biovision, Milpitas, CA, US).

2, activation of caspase-3 and cleavage of poly-(ADP-ribose)polymerase (PARP) was closely associated with the apoptosis induced by isoliquiritigenin. ${ }^{29}$ In this study, to verify the role of mitochondrion in 1e triggered apoptosis, we performed western blots to analyze apoptosis-related proteins. As shown in Fig. 7A, $20 \mu \mathrm{M}$ of $1 \mathrm{e}$ induced an elevated level of Bax, and meanwhile the expression of Bcl-2 was decreased. In addition, decreased protein level of procaspase- 9 and cleaved PARP were found after treatment with $20 \mu \mathrm{M}$ of $1 \mathrm{e}$, indicating that 1e could trigger mitochondrion-dependent apoptosis. In addition, $20 \mu \mathrm{M}$ of $1 \mathrm{e}$ significantly induced an increase in caspase-3 activity (Fig. 7B), which was not found in $10 \mu \mathrm{M}$ of $1 \mathrm{e}$ treatment. Meanwhile, the protein expression of XIAP was found unchanged after treatment with 1e, suggesting that XIAP was not involved in 1e activated caspase-3. The anti-cancer activity of 1e was comparable with other plants derived compounds. For instance, Wang and et al. reported mitochondrion-dependent apoptosis induced by cordycepin at the concentration of $15 \mu \mathrm{M}$ in H1975 cells. ${ }^{25} \mathrm{Lu}$ and et al. found that treatment with $150 \mu \mathrm{g} \mathrm{mL}{ }^{-1}$ of sulfated galactoglucan could activate caspase- 3 in $\mathrm{H} 1975$ cells. $^{30}$ These results indicated that $\mathbf{1 e}$ as a derivative of deacetylisovaltratum obtained from semi-synthesis, achieved superior anticancer activity than the parental compound. Moreover, the anti-proliferation ability was at a similar level of other plants derived compounds.

\section{Conclusion}

In this study, we designed and synthesized of a series of valepotriate derivatives from genipin using slightly modified Murakami's method. Among these derivatives, 1e which contained a novel skeleton with methoxycarbonyl on C4-position and (5methylhexanoyl)oxy group on C-7 position possessed stronger anticancer activity than its parental compound deacetylisovaltratum. Noteworthy, specific SAR has been found: (1) natural derived group at $1^{\text {st }}$ position is better than others; (2) different substituents at the $7^{\text {th }}$ position can be critical for its bioactivity; (3) the length of aliphatic side chain is crucial to its anticancer activity. Finally, 1e has been found with superior potency than lead compound deacetylisovaltratum. In addition, 1e induced mitochondrion-mediated apoptosis was significantly observed, 
which might be the action mechanism of its cytotoxic activities, thus enlightening the further development of novel valepotriate derivatives.

\section{Experimental section}

\subsection{Chemistry}

Proton NMR spectra were obtained on a Bruker AVII 500 or 400 NMR spectrometer (500 or $400 \mathrm{MHz}$ ) by use of $\mathrm{CDCl}_{3}, \mathrm{CD}_{3} \mathrm{OD}$, or DMSO- $_{6}$ as solvent. Carbon-13 NMR spectra were obtained a Bruker spectrometer $(125 \mathrm{MHz})$ by use of $\mathrm{CDCl}_{3} \mathrm{CD}_{3} \mathrm{OD}$ or DMSO-d6 as solvent. Carbon-13 chemical shifts are referenced to the central peak of $\mathrm{CDCl}_{3}(\mathrm{~d} 77.0 \mathrm{ppm})$ or DMSO-d6 (d 39.5 ppm). Multiplicities are recorded by the following abbreviations: s, singlet; $\mathrm{d}$, double; t, triplet; $\mathrm{q}$, quartet; $\mathrm{m}$, multiplet; $J$, coupling constant $(\mathrm{Hz})$. ESI-MS spectra were obtained from Shimadzu LCMS-2020 mass spectrometer. Unless otherwise noted, reagents and solvent were obtained from commercial suppliers and without further purification.

4.1.1 Conversion from genipin (2) to methyl acetal (3). To a solution of genipin $(3.57 \mathrm{~g}, 16.14 \mathrm{mmol})$ in $\mathrm{MeOH}(30 \mathrm{~mL})$ was added Amberlyst-15 (10.51 g). The mixture was stirred rt overnight, and the resulting mixture was filtered and washed by EtOAc, and the combined filtrates were concentrated under reduced pressure to give the light yellow oil. After being purified by silica gel column chromatography $(\mathrm{PE} / \mathrm{EtOAc}=2: 1)$ to afford 3 (3.2 g, 84\%). ${ }^{1} \mathrm{H}$ NMR (500 MHz, $\left.\mathrm{CDCl}_{3}\right) \delta 7.49(\mathrm{~s}, 1 \mathrm{H})$, $5.81(\mathrm{~s}, 1 \mathrm{H}), 4.46(\mathrm{~d}, J=8.1 \mathrm{~Hz}, 1 \mathrm{H}), 4.22(\mathrm{~s}, 2 \mathrm{H}), 3.70(\mathrm{~s}, 3 \mathrm{H})$, 3.56 (s, 3H), 3.17 (q, $J=8.4 \mathrm{~Hz}, 1 \mathrm{H}), 2.85$ (ddd, $J=16.5,8.5$, $1.3 \mathrm{~Hz}, 1 \mathrm{H}), 2.58$ (t, $J=8.0 \mathrm{~Hz}, 1 \mathrm{H}), 2.09-2.02$ (m, 1H). LC-MS: $241(\mathrm{M}+\mathrm{H})$.

4.1.2 Conversion from methyl acetal (3) to phenylsulfide (4). To a solution of $2(10.6 \mathrm{~g}, 44.1 \mathrm{mmol})$ in Tol $(80 \mathrm{~mL})$ was added PhSSPh (8.47 g, $55.2 \mathrm{mmol}$ ) and tributylphosphine (13.2 $\mathrm{mL}, 53.1 \mathrm{mmol})$. The mixture was stirred at $\mathrm{rt}$ for $3 \mathrm{~h}$, the mixture was concentrated under reduced pressure to give a residue, which was purified by silica gel column chromatography (from $\mathrm{PE}$ to $\mathrm{PE} / \mathrm{EtOAc}=10: 1)$ to afford $4(13.88 \mathrm{~g}, 94 \%)$. ${ }^{1} \mathrm{H}$ NMR $\left(500 \mathrm{MHz}, \mathrm{CDCl}_{3}\right) \delta 7.51(\mathrm{~d}, J=0.9 \mathrm{~Hz}, 1 \mathrm{H}), 7.33-7.30$ (m, 2H), 7.29-7.26 (m, 2H), 7.19 (d, J=7.3 Hz, 1H), $5.68(\mathrm{~s}, 1 \mathrm{H})$, $4.51(\mathrm{~d}, J=7.7 \mathrm{~Hz}, 1 \mathrm{H}), 3.71(\mathrm{~s}, 3 \mathrm{H}), 3.62-3.58(\mathrm{~m}, 1 \mathrm{H}), 3.56$ (s, $3 \mathrm{H}), 3.12(\mathrm{td}, J=8.2,0.9 \mathrm{~Hz}, 1 \mathrm{H}), 2.77(\mathrm{dd}, J=16.4,8.5 \mathrm{~Hz}, 2 \mathrm{H})$, 2.05 (dd, $J=8.2,1.4 \mathrm{~Hz}, 1 \mathrm{H})$. LC-MS: $333(\mathrm{M}+\mathrm{H})$.

4.1.3 Conversion from phenylsulfide (4) to hemiacetal (5). To a solution of $4(5.0 \mathrm{~g}, 15.1 \mathrm{mmol})$ in THF $(80 \mathrm{~mL})$ was added aqueous $10 \% \mathrm{HCl}(39 \mathrm{~mL})$. The mixture was stirred at $60{ }^{\circ} \mathrm{C}$ for $16 \mathrm{~h}$. The mixture was cooled to $\mathrm{rt}$ and poured into aqueous saturated $\mathrm{NaHCO}_{3}$, then the whole was extract with EtOAc (50 $\mathrm{mL} \times 3)$. The combined organic layer was washed by aqueous saturated $\mathrm{NaCl}$ and dried over $\mathrm{Na}_{2} \mathrm{SO}_{4}$. Then the organic layer was concentrated under reduced pressure to give a residue, which was purified by silica gel column chromatography (from $\mathrm{PE} / \mathrm{EtOAc}=10: 1$ to $\mathrm{PE} / \mathrm{EtOAc}=2: 1)$ to afford $5(1.98 \mathrm{~g}, 41.3 \%$, $40 \%$ recovery of 4$).{ }^{1} \mathrm{H}$ NMR $\left(500 \mathrm{MHz}, \mathrm{CDCl}_{3}\right) \delta 7.49(\mathrm{~s}, 1 \mathrm{H})$, $7.32(\mathrm{~d}, J=7.5 \mathrm{~Hz}, 2 \mathrm{H}), 7.29-7.24(\mathrm{~m}, 2 \mathrm{H}), 7.18(\mathrm{t}, J=7.3 \mathrm{~Hz}$, $1 \mathrm{H}), 5.71$ (s, 1H), 4.85 (d, $J=8.3 \mathrm{~Hz}, 1 \mathrm{H}), 3.87$ (d, $J=14.4 \mathrm{~Hz}$, $1 \mathrm{H}), 3.71(\mathrm{~s}, 3 \mathrm{H}), 3.58(\mathrm{t}, J=6.6 \mathrm{~Hz}, 1 \mathrm{H}), 3.12(\mathrm{q}, J=8.2 \mathrm{~Hz}, 1 \mathrm{H})$, $2.79(\mathrm{dd}, J=16.5,8.6 \mathrm{~Hz}, 1 \mathrm{H}), 2.69(\mathrm{t}, J=7.5 \mathrm{~Hz}, 1 \mathrm{H}), 2.03-1.97$ (m, 1H), 1.87 (dd, $J=14.8,6.8 \mathrm{~Hz}, 1 \mathrm{H}), 1.76-1.68$ (m, 1H). LCMS: $319(\mathrm{M}+\mathrm{H})$.

4.1.4 Conversion from hemiacetal (5) to hemiester (6). A solution of CDI $(14.4 \mathrm{~g}, 88 \mathrm{mmol})$ in $\mathrm{CH}_{2} \mathrm{Cl}_{2}(70 \mathrm{~mL})$ was treated with isovaleric acid $(14.0 \mathrm{~mL}, 88 \mathrm{mmol})$ and $\mathrm{DBU}(264 \mu \mathrm{L}, 1.76$ $\mathrm{mmol}$ ) at $0{ }^{\circ} \mathrm{C}$ for $10 \mathrm{~min}$. The mixture was added to a solution of the $5(2.8 \mathrm{~g}, 8.8 \mathrm{mmol})$ in $\mathrm{CH}_{2} \mathrm{Cl}_{2}(10 \mathrm{~mL})$, then the whole was stirred at rt overnight. After the reaction mixture was poured into aqueous saturated $\mathrm{NaCl}$, the whole was extracted with EtOAc. The organic layer was successively washed with 5\% aqueous $\mathrm{HCl}$, aqueous saturated $\mathrm{NaHCO}_{3}$, and aqueous saturated $\mathrm{NaCl}$ and dried over $\mathrm{Na}_{2} \mathrm{SO}_{4}$. Concentrate the organic layer under reduced pressure to give a residue, which was purified by silica gel column chromatography $(\mathrm{PE} / \mathrm{EtOAc}=10: 1)$ to afford 6a $(2.8 \mathrm{~g}, 80 \%) .{ }^{1} \mathrm{H}$ NMR $\left(500 \mathrm{MHz}, \mathrm{CDCl}_{3}\right) \delta 7.44(\mathrm{~d}, J=1.1 \mathrm{~Hz}$, 1H), 7.33-7.26 (m, 4H), 7.20 (ddd, $J=7.2,3.9,1.3 \mathrm{~Hz}, 1 \mathrm{H}), 5.95$ $(\mathrm{d}, J=6.9 \mathrm{~Hz}, 1 \mathrm{H}), 5.67(\mathrm{~s}, 1 \mathrm{H}), 3.76(\mathrm{~d}, J=14.2 \mathrm{~Hz}, 1 \mathrm{H}), 3.71(\mathrm{~s}$, $3 \mathrm{H}), 3.49-3.44(\mathrm{~m}, 1 \mathrm{H}), 3.19$ (dd, $J=11.4,4.5 \mathrm{~Hz}, 1 \mathrm{H}), 2.97$ (t, $J=$ $7.3 \mathrm{~Hz}, 1 \mathrm{H}), 2.76$ (dd, $J=16.7,8.2 \mathrm{~Hz}, 1 \mathrm{H}), 2.31-2.07(\mathrm{~m}, 4 \mathrm{H})$, $0.96(\mathrm{dd}, J=6.6,4.2 \mathrm{~Hz}, 6 \mathrm{H})$. LC-MS: $425\left(\mathrm{M}+\mathrm{Na}^{+}\right)$.

4.1.5 Conversion from 6 to alcohol (7). To a solution of 6 (750 $\mathrm{mg}, 1.87 \mathrm{mmol}$ ) in $\mathrm{MeOH}(30 \mathrm{~mL})$ was added oxone (687 mg, $1.11 \mathrm{mmol}$ ) at $0{ }^{\circ} \mathrm{C}$ for $1 \mathrm{~h}$. Then the reaction was quenched by aqueous saturated $\mathrm{Na}_{2} \mathrm{SO}_{3}$ for $10 \mathrm{~min}$, and the mixture was extracted with EtOAc. The organic layer was washed by aqueous saturated $\mathrm{NaCl}$ and dried over $\mathrm{Na}_{2} \mathrm{SO}_{4}$. Concentration of the organic layer under reduced pressure gave the crude sulfoxide. To a solution of crude sulfoxide in $\mathrm{MeOH}(20 \mathrm{~mL})$ was added $(\mathrm{MeO})_{3} \mathrm{P}(331 \mu \mathrm{L}, 2.8 \mathrm{mmol})$ and the mixture was heated under reflux for $5 \mathrm{~h}$. After it's fully reacted, the mixture was cooled to rt and poured into aqueous saturated $\mathrm{NaCl}$, then the mixture was extracted by EtOAc, and the organic layer was washed by aqueous saturated $\mathrm{NaCl}$ and dried over $\mathrm{Na}_{2} \mathrm{SO}_{4}$. Concentrate the organic layer under reduced pressure to give a residue, which was purified by silica gel column chromatography $(\mathrm{PE} / \mathrm{EtOAc}=2: 1)$ to afford $7(430 \mathrm{mg}, 80 \%) .{ }^{1} \mathrm{H}$ NMR $(500$ $\left.\mathrm{MHz} \mathrm{CDCl}_{3}\right) \delta 7.56-7.53(\mathrm{~m}, 1 \mathrm{H}), 7.42(\mathrm{~d}, J=1.2 \mathrm{~Hz}, 1 \mathrm{H}), 7.35$ (dd, $J=4.3,3.1 \mathrm{~Hz}, 1 \mathrm{H}), 5.89(\mathrm{~d}, J=6.7 \mathrm{~Hz}, 1 \mathrm{H}), 5.43-5.40(\mathrm{~m}$, $1 \mathrm{H}), 5.31(\mathrm{t}, J=1.8 \mathrm{~Hz}, 1 \mathrm{H}), 4.48(\mathrm{t}, J=4.2 \mathrm{~Hz}, 1 \mathrm{H}), 4.10(\mathrm{q}, J=$ $7.1 \mathrm{~Hz}, 1 \mathrm{H}), 3.81(\mathrm{~d}, J=12.7 \mathrm{~Hz}, 3 \mathrm{H}), 3.72(\mathrm{~s}, 3 \mathrm{H}), 3.25(\mathrm{~d}, J=$ $7.4 \mathrm{~Hz}, 1 \mathrm{H}), 2.95-2.89(\mathrm{~m}, 1 \mathrm{H}), 2.31-2.21$ (m, 2H), 2.18 (ddd, $J=$ 13.5, 6.7, $4.4 \mathrm{~Hz}, 1 \mathrm{H}), 2.12(\mathrm{dt}, J=13.7,6.8 \mathrm{~Hz}, 1 \mathrm{H}), 2.03(\mathrm{~s}, 2 \mathrm{H})$, 1.89 (ddd, $J=13.7,8.0,6.0 \mathrm{~Hz}, 1 \mathrm{H}), 1.24$ (t, $J=7.1 \mathrm{~Hz}, 2 \mathrm{H}), 0.96$ (dd, $J=6.6,2.6 \mathrm{~Hz}, 7 \mathrm{H}), 0.90-0.78(\mathrm{~m}, 1 \mathrm{H})$. LC-MS: $311(\mathrm{M}+\mathrm{H})$.

4.1.6 Conversion from alcohol (7a) to target compound $1 \mathrm{a}$ to $1 \mathrm{~h}$. To a solution of $7(46.5 \mathrm{mg}, 0.15 \mathrm{mmol})$ in toluene $(10 \mathrm{~mL})$ was added $\mathrm{VO}(\mathrm{acac})_{2}(3.9 \mathrm{mg}, 0.015 \mathrm{mmol})$ and $70 \%$ TBHP (62 $\mu \mathrm{L}, 0.45 \mathrm{mmol}$ ) until 7 was fully consumed. Then, the reaction was quenched by aqueous saturated $\mathrm{NaHCO}_{3}$ for $15 \mathrm{~min}$, and the mixture was extracted with EtOAc. The organic layer was washed by aqueous saturated $\mathrm{NaCl}$ and dried over $\mathrm{Na}_{2} \mathrm{SO}_{4}$. The crude epoxide was given by the concentration of organic layer under reduced pressure. Under the protection of $\mathrm{N}_{2}$, the solution of crude epoxide in toluene was added DEAD $(56 \mu \mathrm{L}, 0.15 \mathrm{mmol})$ at the presence of $\mathrm{Ph}_{3} \mathrm{P}$ and acid at $0{ }^{\circ} \mathrm{C}$. Then, the mixture was stirred at $\mathrm{rt}$ for $2 \mathrm{~h}$. The whole was concentrated under reduced 
pressure and directly purified by silica gel column chromatography $(\mathrm{PE} / \mathrm{EtOAc}=10: 1)$ to afford the target compounds.

Compound 1a (26.6 mg, 43.2\%): colorless oil ${ }^{1} \mathrm{H}$ NMR (500 $\left.\mathrm{MHz}_{\mathrm{CDCl}}\right) \delta 7.42(\mathrm{~d}, J=1.0 \mathrm{~Hz}, 1 \mathrm{H}), 6.11(\mathrm{~d}, J=5.6 \mathrm{~Hz}, 1 \mathrm{H})$, $5.03(\mathrm{dd}, J=7.7,4.1 \mathrm{~Hz}, 1 \mathrm{H}), 3.73(\mathrm{~d}, J=3.1 \mathrm{~Hz}, 3 \mathrm{H}), 3.25(\mathrm{~d}, J=$ $7.4 \mathrm{~Hz}, 1 \mathrm{H}), 3.06$ (d, $J=4.6 \mathrm{~Hz}, 1 \mathrm{H}), 2.95$ (d, $J=4.6 \mathrm{~Hz}, 1 \mathrm{H})$, 2.86-2.75 (m, 1H), $2.37(\mathrm{dd}, J=7.7,5.6 \mathrm{~Hz}, 1 \mathrm{H}), 2.24(\mathrm{t}, J=$ $6.8 \mathrm{~Hz}, 2 \mathrm{H}), 2.10(\mathrm{t}, J=6.1 \mathrm{~Hz}, 3 \mathrm{H}), 2.04-1.98(\mathrm{~m}, 1 \mathrm{H}), 1.89(\mathrm{dd}, J$ $=14.8,1.4 \mathrm{~Hz}, 1 \mathrm{H}), 0.96(\mathrm{dd}, J=6.6,1.8 \mathrm{~Hz}, 6 \mathrm{H}), 0.91(\mathrm{~d}, J=$ $6.6 \mathrm{~Hz}, 6 \mathrm{H}) .{ }^{13} \mathrm{C} \mathrm{NMR}\left(126 \mathrm{MHz}, \mathrm{CDCl}_{3}\right) \delta 170.92,170.04,165.64$, 150.33, 109.57, 87.30, 76.21, 75.26, 64.40, 50.41, 47.01, 42.25, 42.04, 41.74, 36.07, 29.85, 24.61, 24.59, 21.30, 21.24. LC-MS: 411 $(\mathrm{M}+\mathrm{H})$.

Compound $1 \mathrm{~b}(28.5 \mathrm{mg}, 51.6 \%)$ : colorless oil ${ }^{1} \mathrm{H}$ NMR $(500$ $\left.\mathrm{MHz} \mathrm{CDCl}_{3}\right) \delta 7.41(\mathrm{~d}, J=1.3 \mathrm{~Hz}, 1 \mathrm{H}), 6.12(\mathrm{~d}, J=5.8 \mathrm{~Hz}, 1 \mathrm{H})$, $5.00(\mathrm{dd}, J=7.7,4.4 \mathrm{~Hz}, 1 \mathrm{H}), 3.74(\mathrm{~s}, 3 \mathrm{H}), 3.25$ (d, $J=7.7 \mathrm{~Hz}$, $1 \mathrm{H}), 3.05$ (d, $J=4.6 \mathrm{~Hz}, 1 \mathrm{H}), 2.97$ (d, $J=4.6 \mathrm{~Hz}, 1 \mathrm{H}), 2.82(\mathrm{dd}, J=$ 7.8, 7.0 Hz, 1H), 2.59 (s, 3H), 2.34 (dd, $J=7.6,5.9 \mathrm{~Hz}, 1 \mathrm{H}), 2.24$ (dd, $J=7.1,5.9 \mathrm{~Hz}, 2 \mathrm{H}), 2.15-2.06(\mathrm{~m}, 1 \mathrm{H}), 1.90-1.83(\mathrm{~m}, 1 \mathrm{H})$, 0.96 (dd, $J=6.6,1.9 \mathrm{~Hz}, 6 \mathrm{H})$. LC-MS: 369 (M+ H).

Compound 1c (27 mg, 41.2\%): ${ }^{1} \mathrm{H}$ NMR (500 $\mathrm{MHz}, \mathrm{CDCl}_{3}$ ) $\delta 7.42(\mathrm{~d}, J=1.2 \mathrm{~Hz}, 1 \mathrm{H}), 6.10(\mathrm{~d}, J=5.3 \mathrm{~Hz}, 1 \mathrm{H}), 5.01(\mathrm{dd}, J=$ 7.6, $3.8 \mathrm{~Hz}, 1 \mathrm{H}), 3.73(\mathrm{~s}, 3 \mathrm{H}), 3.25$ (dd, $J=13.5,6.6 \mathrm{~Hz}, 1 \mathrm{H}), 3.06$ $(\mathrm{d}, J=4.6 \mathrm{~Hz}, 1 \mathrm{H}), 2.93(\mathrm{~d}, J=4.6 \mathrm{~Hz}, 1 \mathrm{H}), 2.80-2.73(\mathrm{~m}, 1 \mathrm{H})$, $2.39(\mathrm{dd}, J=7.6,5.3 \mathrm{~Hz}, 1 \mathrm{H}), 2.23(\mathrm{dd}, J=15.4,8.6 \mathrm{~Hz}, 3 \mathrm{H}), 2.10$ $(\mathrm{m}, 1 \mathrm{H}), 1.91(\mathrm{ddd}, J=14.9,5.3,3.9 \mathrm{~Hz}, 1 \mathrm{H}), 1.79(\mathrm{~s}, 2 \mathrm{H}), 1.70(\mathrm{~s}$, $2 \mathrm{H}), 1.62$ (d, $J=9.5 \mathrm{~Hz}, 1 \mathrm{H}), 1.57$ (d, $J=4.1 \mathrm{~Hz}, 3 \mathrm{H}), 1.40-1.31$ $(\mathrm{m}, 2 \mathrm{H}), 0.96(\mathrm{dd}, J=6.6,1.9 \mathrm{~Hz}, 6 \mathrm{H}) .{ }^{13} \mathrm{C}$ NMR $(126 \mathrm{MHz}$, $\left.\mathrm{CDCl}_{3}\right) \delta 174.83,171.08,166.65,151.35,110.59,88.27,77.23$, 76.24, 65.55, 51.41, 48.01, 43.06, 42.85, 37.02, 30.93, 28.79, 28.75, 25.66, 25.62, 25.35, 25.31, 22.26. LC-MS: 437 (M+ H).

Compound 1d (24 mg, 37.2\%): colorless oil ${ }^{1} \mathrm{H}$ NMR (500 $\left.\mathrm{MHz} \mathrm{CDCl}_{3}\right) \delta 7.94(\mathrm{dd}, J=8.3,1.2 \mathrm{~Hz}, 2 \mathrm{H}), 7.56(\mathrm{~s}, 1 \mathrm{H}), 7.49(\mathrm{~d}$, $J=1.3 \mathrm{~Hz}, 1 \mathrm{H}), 7.43(\mathrm{t}, J=7.8 \mathrm{~Hz}, 2 \mathrm{H}), 6.20(\mathrm{~d}, J=5.1 \mathrm{~Hz}, 1 \mathrm{H})$, $5.30(\mathrm{~s}, 1 \mathrm{H}), 3.67(\mathrm{~s}, 3 \mathrm{H}), 3.33(\mathrm{dt}, J=7.7,6.4 \mathrm{~Hz}, 1 \mathrm{H}), 3.12(\mathrm{~d}, J=$ $4.5 \mathrm{~Hz}, 1 \mathrm{H}), 3.04(\mathrm{~d}, J=4.5 \mathrm{~Hz}, 1 \mathrm{H}), 2.90-2.81$ (m, 1H), 2.48 (dd, $J=7.6,5.2 \mathrm{~Hz}, 1 \mathrm{H}), 2.25(\mathrm{t}, J=6.9 \mathrm{~Hz}, 2 \mathrm{H}), 2.18-2.07(\mathrm{~m}, 2 \mathrm{H})$, 0.96 (dd, $J=6.6,3.5 \mathrm{~Hz}, 6 \mathrm{H}) .{ }^{13} \mathrm{C} \mathrm{NMR}\left(126 \mathrm{MHz}, \mathrm{CDCl}_{3}\right.$ ) $\delta 171.14,166.60,165.41,151.32,133.31,129.67,128.43,110.70$, $88.25,77.43,77.23,65.72,51.40,48.20,43.07,37.02,31.17$, 25.65, 22.26. LC-MS: $431(\mathrm{M}+\mathrm{H})$.

Compound 1e (30 mg, 44.2\%): colorless oil ${ }^{1} \mathrm{H}$ NMR (500 $\left.\mathrm{MHz} \mathrm{CDCl}_{3}\right) \delta 7.42(\mathrm{~s}, 1 \mathrm{H}), 6.10(\mathrm{~d}, J=5.3 \mathrm{~Hz}, 1 \mathrm{H}), 5.05(\mathrm{dt}, J=$ 7.5, $3.8 \mathrm{~Hz}, 1 \mathrm{H}), 3.73$ (d, $J=2.4 \mathrm{~Hz}, 3 \mathrm{H}), 3.26$ (dd, $J=13.7$, $7.3 \mathrm{~Hz}, 1 \mathrm{H}), 3.06$ (dd, $J=4.5,2.2 \mathrm{~Hz}, 1 \mathrm{H}), 2.91$ (d, $J=4.6 \mathrm{~Hz}$, $1 \mathrm{H}), 2.78(\mathrm{dtd}, J=10.6,7.8,2.9 \mathrm{~Hz}, 1 \mathrm{H}), 2.41-2.36(\mathrm{~m}, 1 \mathrm{H}), 2.28-$ $2.20(\mathrm{~m}, 2 \mathrm{H}), 2.20-2.14(\mathrm{~m}, 1 \mathrm{H}), 2.10(\mathrm{dt}, J=13.6,6.8 \mathrm{~Hz}, 1 \mathrm{H})$, 1.93-1.86 (m, 1H), 1.56-1.36 (m, 4H), 1.30-1.25 (m, 2H), 1.21$1.12(\mathrm{~m}, 2 \mathrm{H}), 0.99-0.94(\mathrm{~m}, 6 \mathrm{H}), 0.89-0.78(\mathrm{~m}, 6 \mathrm{H}) .{ }^{13} \mathrm{C}$ NMR $\left(126 \mathrm{MHz}, \mathrm{CDCl}_{3}\right) \delta 175.15,175.07,171.07,166.64,151.38$, $110.60,88.29,88.28,77.25,76.28,76.22,65.62,51.42,48.08$, $48.05,47.35,47.19,43.06,42.88,37.17,31.58,31.51,31.05$, 29.53, 29.52, 25.61, 25.32, 25.27, 22.57, 22.51, 22.27. LC-MS: 453 $(\mathrm{M}+\mathrm{H})$.

Compound 1f (30 mg, 47.2\%): colorless oil ${ }^{1} \mathrm{H}$ NMR (500 $\left.\mathrm{MHz} \mathrm{CDCl}_{3}\right) \delta 7.42(\mathrm{~d}, J=1.3 \mathrm{~Hz}, 1 \mathrm{H}), 6.11(\mathrm{~d}, J=5.6 \mathrm{~Hz}, 1 \mathrm{H})$, $5.02(\mathrm{dd}, J=7.7,4.2 \mathrm{~Hz}, 1 \mathrm{H}), 3.74(\mathrm{~s}, 3 \mathrm{H}), 3.25$ (d, $J=7.6 \mathrm{~Hz}$,
$1 \mathrm{H}), 3.05(\mathrm{~d}, J=4.6 \mathrm{~Hz}, 1 \mathrm{H}), 2.95(\mathrm{dd}, J=9.8,5.2 \mathrm{~Hz}, 2 \mathrm{H}), 2.85-$ $2.75(\mathrm{~m}, 1 \mathrm{H}), 2.36(\mathrm{dd}, J=7.7,5.7 \mathrm{~Hz}, 1 \mathrm{H}), 2.26-2.19(\mathrm{~m}, 4 \mathrm{H})$, 2.14-2.06 (m, 1H), 1.87 (ddd, $J=14.8,5.9,4.3 \mathrm{~Hz}, 1 \mathrm{H}), 1.68$ (s, $1 \mathrm{H}), 1.57-1.52(\mathrm{~m}, 2 \mathrm{H}), 1.34$ (dd, $J=7.4,3.6 \mathrm{~Hz}, 2 \mathrm{H}), 0.96$ (dd, $J$ $=6.6,2.0 \mathrm{~Hz}, 6 \mathrm{H}), 0.89-0.86(\mathrm{~m}, 3 \mathrm{H})$. LC-MS: $425(\mathrm{M}+\mathrm{H})$.

Compound $1 \mathrm{~g}$ (15 mg, 22.1\%): colorless oil ${ }^{1} \mathrm{H}$ NMR (500 $\left.\mathrm{MHz}, \mathrm{CDCl}_{3}\right) \delta 7.42(\mathrm{~d}, J=1.1 \mathrm{~Hz}, 1 \mathrm{H}), 6.11(\mathrm{~d}, J=5.6 \mathrm{~Hz}, 1 \mathrm{H})$, $5.01(\mathrm{dd}, J=7.7,4.2 \mathrm{~Hz}, 1 \mathrm{H}), 3.74(\mathrm{~s}, 3 \mathrm{H}), 3.25(\mathrm{~d}, J=7.5 \mathrm{~Hz}, 1 \mathrm{H})$, 3.05 (d, $J=4.6 \mathrm{~Hz}, 1 \mathrm{H}), 2.95$ (d, $J=4.7 \mathrm{~Hz}, 2 \mathrm{H}), 2.85-2.76(\mathrm{~m}$, $1 \mathrm{H}), 2.36$ (dd, $J=7.6,5.8 \mathrm{~Hz}, 1 \mathrm{H}), 2.28-2.18$ (m, 4H), 2.14-2.07 (m, $1 \mathrm{H}), 1.87$ (ddd, $J=14.8,5.8,4.4 \mathrm{~Hz}, 1 \mathrm{H}), 1.67$ (td, $J=14.5$, $7.0 \mathrm{~Hz}, 1 \mathrm{H}), 1.58-1.50(\mathrm{~m}, 2 \mathrm{H}), 1.25$ (d, $J=4.0 \mathrm{~Hz}, 7 \mathrm{H}), 0.96(\mathrm{dd}, J$ $=6.6,2.0 \mathrm{~Hz}, 6 \mathrm{H}), 0.87(\mathrm{t}, J=6.9 \mathrm{~Hz}, 3 \mathrm{H})$. LC-MS: $453(\mathrm{M}+\mathrm{H})$.

Compound $1 \mathrm{~h}(18 \mathrm{mg}, 25.0 \%)$ : colorless oil ${ }^{1} \mathrm{H}$ NMR (500 $\left.\mathrm{MHz}, \mathrm{CDCl}_{3}\right) \delta 7.41(\mathrm{~d}, J=1.1 \mathrm{~Hz}, 1 \mathrm{H}), 6.11(\mathrm{~d}, J=5.7 \mathrm{~Hz}, 1 \mathrm{H})$, $5.01(\mathrm{dd}, J=7.7,4.2 \mathrm{~Hz}, 1 \mathrm{H}), 3.73(\mathrm{~s}, 3 \mathrm{H}), 3.29-3.19(\mathrm{~m}, 1 \mathrm{H}), 3.05$ $(\mathrm{d}, J=4.6 \mathrm{~Hz}, 1 \mathrm{H}), 2.95(\mathrm{~d}, J=4.6 \mathrm{~Hz}, 1 \mathrm{H}), 2.81(\mathrm{dt}, J=15.4$, $7.9 \mathrm{~Hz}, 1 \mathrm{H}), 2.36$ (dd, $J=7.6,5.8 \mathrm{~Hz}, 1 \mathrm{H}), 2.26-2.19(\mathrm{~m}, 4 \mathrm{H}), 2.10$ (dt, $J=13.6,6.8 \mathrm{~Hz}, 1 \mathrm{H}), 1.87$ (ddd, $J=14.8,5.8,4.4 \mathrm{~Hz}, 1 \mathrm{H}$ ), 1.57-1.50 (m, 2H), 1.25 (s, 12H), $0.96(\mathrm{dd}, J=6.6,2.0 \mathrm{~Hz}, 6 \mathrm{H}), 0.87$ $(\mathrm{t}, J=6.9 \mathrm{~Hz}, 3 \mathrm{H}) .{ }^{13} \mathrm{C} \mathrm{NMR}\left(126 \mathrm{MHz}, \mathrm{CDCl}_{3}\right) \delta 172.67,171.06$, 166.68, 151.33, 110.64, 88.36, 77.23, 76.28, 65.38, 51.45, 47.97, $43.08,42.74,37.10,34.25,31.85,30.82$, 29.40, 29.25, 29.22, 29.09, 25.62, 24.79, 22.66, 22.27, 22.25, 14.10. LC-MS: $481(\mathrm{M}+\mathrm{H})$.

\subsection{Pharmacological assay}

RPMI-1640 medium and fetal bovine serum (FBS) were purchased from Gibco, BRL (Grand Island, NY, USA). Human pancreatic cancer cell lines (SW1990, BXPC3, CAPAN2, CFPAC, PANC1), human breast cancer cell lines (BT474, MCF7, MDAMB-231), human lung cancer cell line (H1975) and human gastric cancer cell lines (AGC, HGC-27, KATOIII) were purchased from Shanghai Institutes for Biological Sciences, CAS (Shanghai, China). DAPI was purchased from SigmaAldrich (St Louis, MO, US). The Annexin V-FITC Apoptosis Kit was purchased from BD (Franklin Lakes, NJ, US). The primary antibodies against Bax, Bcl-2, Mcl-1, procaspase-9, poly-ADPribose polymerase (PARP), XIAP and $\beta$-actin were purchased from Abcam Inc. (Cambridge, MA, US). Caspase-3 Colorimetric Assay Kit was purchased from Biovision (Milpitas, CA, US). Human lung cancer cell line H1975 was purchased from Shanghai Institutes for Biological Sciences, CAS (Shanghai, China). Cells were cultured with RPMI-1640 medium containing $10 \%$ fetal bovine serum (FBS) and 1\% penicillin/streptomycin at $37{ }^{\circ} \mathrm{C}, 5 \% \mathrm{CO}_{2}$ humidified atmosphere. 1e was dissolved in DMSO at the concentration of $100 \mathrm{mM}$.

4.2.1 Cell viability assay. H1975 cells were counted in logarithmic phase and 5000 cells were placed in 96-well plates. After treatment with $1 \mathrm{e}(10,20$ and $30 \mu \mathrm{M})$, cells were incubated for an additional $2 \mathrm{~h}$ with CCK-8 reagent $(100 \mu \mathrm{L}$ per $\mathrm{mL}$ medium) and the absorbance was read at $450 \mathrm{~nm}$ using a microplate reader (Sunnyvale, CA, USA). Cell proliferation inhibition rates were calculated according to the following formula: the proliferation inhibition ratio (\%) $=1-\left[\left(A_{1}-A_{3}\right) /\right.$ $\left.\left(A_{2}-A_{3}\right)\right] \times 100$, where, $A_{1}$ is the OD value of drug experimental group, $A_{2}$ is the OD value of blank control group, $A_{3}$ is the OD 
value of the RPMI1640 medium without cells. The $\mathrm{IC}_{50}(50 \%$ inhibitory concentration) value, which represents the concentration of the drug that demonstrates $50 \%$ of cell growth inhibition, was calculated by nonlinear regression analysis using GraphPad Prism software (San Diego, CA, USA). Assays were performed on three independent experiments.

4.2.2 DAPI stain. H1975 cells $\left(2 \times 10^{4}\right.$ cells per well $)$ were cultured in 24-well plates. After treatment with $1 \mathrm{e}$ for $48 \mathrm{~h}$, cells were fixed with $4 \%$ paraformaldehyde for $20 \mathrm{~min}$, and stained with DAPI for $20 \mathrm{~min}$ at $37^{\circ} \mathrm{C}$. After washing with PBS, cells were observed under a fluorescence microscope (Nikon, Ti-E, Japan).

4.2.3 Apoptosis assay by flow cytometry. Exponentially growing cells were seeded in 6 -well plates $\left(5 \times 10^{4}\right.$ per well $)$ and cultured overnight in a $5 \% \mathrm{CO}_{2}$ atmosphere at $37{ }^{\circ} \mathrm{C}$. After treatment with 1e for $24 \mathrm{~h}$, cells were harvested and washed with PBS. Then cells were stained with Annexin V-FITC Apoptosis Kit according to the manufacturer's instructions and analyzed by flow cytometry (Becton Dickinson, Franklin Lakes, NJ, US). Assays were performed on three independent experiments.

4.2.4 Caspase-3 activity assay. Caspase-3 Colorimetric Assay Kit was used to evaluate caspase-3 activity. In brief, cell lysates were prepared after treatment with 1e $(10$ or $20 \mu \mathrm{M})$ for $48 \mathrm{~h}$. Equal amounts of protein $(200 \mu \mathrm{g})$ were incubated with the supplied reaction buffer and the colorimetric substrates at $37^{\circ} \mathrm{C}$ for $2 \mathrm{~h}$ in the dark. Chromophore pNA released from the cleavage of peptide can be quantified using Molecular Devices $\mathrm{M} 2{ }^{\mathrm{e}}$ (Sunnyvale, CA, US) at the wavelength of $405 \mathrm{~nm}$. Caspase- 3 activity was expressed by value of OD405 relative to control.

4.2.5 Western blot analysis. After treated with 1e, total proteins were extracted using RIPA Lysing Buffer. An amount of $40 \mu \mathrm{g}$ proteins were subjected to $12 \%$ SDS-PAGE and transferred to PVDF Membrane (Bio-Rad, Hercules, CA, USA). The membranes were blocked with $5 \%$ non-fat milk at room temperature for $1 \mathrm{~h}$, and then incubated with specific primary antibodies overnight at $4{ }^{\circ} \mathrm{C}$. After washing with TBST, the membranes were incubated with secondary antibodies at room temperature for another $1 \mathrm{~h}$. The protein bands were visualized by adding ECL system WBKLS0050 (EMD Millipore, Billerica, MA, USA) and analyzed using Bio-Rad Laboratories Quantity One software (Bio-Rad, Hercules, CA, USA).

\section{Acknowledgements}

This work was supported by Hangzhou Major Science and Technology Project (20112312A01, Shenglin Ma; 20172016A01, Nengming Lin), National Natural Science Foundation of China (81603144, Bo Zhang), Natural Science Foundation of Zhejiang Province (LQ15H310001, Bo Zhang), Scientific Research Foundation of Zhejiang Health and Family Planning Commission (2015KYA177, Bo Zhang), Fundamental Research Funds for the Central Universities (2016QNA7030, Xiaoyang Dai), Science and Technology Project of Zhejiang Province (2016C33067, Xiaowu Dong).

\section{References}

1 Y. Fukuyama, Y. Minoshima, Y. Ishimoto, I. S. Chen, H. Takahashi and T. Esumi, J. Nat. Prod., 2004, 67, 1833-1838.
2 W. Hui-lian, Z. Dong-fang, L. Zhao-feng, L. Yang, L. i. Qianrong and W. Yu-zhen, Toxicol. Appl. Pharmacol., 2003, 188, 36-41.

3 C. Bounthanh, C. Bergmann, J. P. Beck, M. Haagberrurier and R. Anton, Planta Med., 1981, 41, 21-28.

4 N. T. Doan, F. Crestey, C. E. Olsen and S. B. Christensen, J. Nat. Prod., 2015, 78, 1406-1414.

5 L. D. Kapoor, Handbook of Ayurvedic medicinal plants, CRC Press, Boca Raton, 2001.

6 B. P. Mikhova, N. V. Handjieva, S. S. Popov and S. L. Spassov, J. Nat. Prod., 1987, 50, 1141-1145.

7 H. Becker, S. Chavadej, P. W. Thies and E. Finner, Planta Med., 1984, 50, 245-248.

8 W. Kucaba, P. W. Thies and E. Finner, Phytochemistry, 1980, 19, 575-577.

9 N. Handjieva and V. G. Zaikin, Planta Med., 1978, 34, 203-206. 10 B. M. Dietz, A. Hajirahimkhan, T. L. Dunlap and J. L. Bolton, Pharmacol. Rev., 2016, 68, 1026-1073.

11 X. Li, T. Chen, S. Lin, J. Zhao, P. Chen, Q. Ba, H. Guo, Y. Liu, J. Li, R. Chu, L. Shan, W. Zhang and H. Wang, Curr. Cancer Drug Targets, 2013, 13, 472-483.

12 R. Bos, H. Hendriks, J. J. C. Scheffer and H. J. Woerdenbag, Phytomedicine, 1998, 5, 219-225.

13 S. Lin, T. Chen, P. Fu, J. Ye, X.-W. Yang, L. Shan, H. L. Li, R. H. Liu, Y. H. Shen, X. K. Xu and W. D. Zhang, J. Asian Nat. Prod. Res., 2015, 17, 455-461.

14 O. Kelber, T. Wegener, B. Steinhoff, C. Staiger, J. Wiesner, W. Knoess and K. Kraft, Phytomedicine, 2014, 21, 1124-1129.

15 D. Zhang, B. Zhang, L. X. Zhou, J. Zhao, Y. Y. Yan, Y. L. Li, J. M. Zeng, L. L. Wang, B. Yang and N. M. Lin, Acta Pharmacol. Sin., 2016, 37, 1597-1605.

16 B. Yang, N. Li, Y. Q. Wang, J. Chen and R. S. Zhang, Rev. Bras. Farmacogn., 2011, 21, 471-476.

17 S. Tamura, K. Fujiwara, N. Shimizu, S. Todo and N. Murakami, Bioorg. Med. Chem., 2010, 18, 5975-5980.

18 H. Hussain, I. R. Green and I. Ahmed, Chem. Rev., 2013, 113, 3329-3371.

19 X. W. Dong, J. Chen, C. Y. Jiang, T. Liu and Y. Z. Hu, Arch. Pharm., 2009, 342, 428-432.

20 H. Jing, X. L. Zhou, X. W. Dong, J. Cao, H. Zhu, J. S. Lou, Y. Z. Hu, Q. J. He and B. Yang, Cancer Lett., 2010, 294, 167-177.

21 K. B. Sharpless and R. F. Lauer, J. Am. Chem. Soc., 1973, 95, 2697-2699.

22 S. Tamura, K. Fujiwara, N. Shimizu, S. Todo and N. Murakami, Bioorg. Med. Chem., 2010, 18, 5975-5980.

23 S. Lin, P. Fu, T. Chen, J. Ye, X. W. Yang and W. D. Zhang, J. Asian Nat. Prod. Res., 2017, 19, 15-21.

24 X. Li, X. X. Fan, Z. B. Jiang, W. T. Loo, X. J. Yao, E. L. Leung, L. W. Chow and L. Liu, Pharmacol. Res., 2017, 115, 45-55.

25 Z. Wang, X. Wu, Y. N. Liang, L. Wang, Z. X. Song, J. L. Liu and Z. S. Tang, Molecules, 2016, 21(10), 1267.

26 L. H. Li, P. Wu, J. Y. Lee, P. R. Li, W. Y. Hsieh, C. C. Ho, C. L. Ho, W. J. Chen, C. C. Wang, M. Y. Yen, S. M. Yang and H. W. Chen, PLoS One, 2014, 9, e104203.

27 N. Khan, F. Jajeh, M. I. Khan, E. Mukhtar, S. M. Shabana and H. Mukhtar, Carcinogenesis, 2017, 38, 184-195. 
28 Y. Du, W. Chen, X. Fu, H. Deng and J. Deng, RSC Adv., 2016, 6, 109718-109725.

29 S. K. Jung, M. H. Lee, D. Y. Lim, J. E. Kim, P. Singh, S. Y. Lee, C. H. Jeong, T. G. Lim, H. Chen, Y. I. Chi, J. K. Kundu,
N. H. Lee, C. C. Lee, Y. Y. Cho, A. M. Bode, K. W. Lee and Z. Dong, J. Biol. Chem., 2014, 289, 35839-35848.

30 M. K. Lu, T. Y. Lin, C. H. Hu, C. H. Chao, C. C. Chang and H. Y. Hsu, Carbohydr. Polym., 2017, 167, 229-239. 